\title{
研究課題別事後評価結果
}

1. 研究課題名

低環境負荷エネルギー用複合機能構造材料の開発研究

2. 研究代表者名及び主たる研究参加者名（研究機関名・職名は研究参加期間終了時点）

研究代表者香山 晃京都大学工ネルギー理工学研究所 教授

主たる研究参加者 加藤 雄大 京都大学エネルギー理工学研究所 助教授

野田 哲二 ナノマテリアル 研究主幹

阿部 信行 大阪大学接合科学研究所 助教授

岡村 清人 大阪府立大学工学部 教授

3. 研究内容及び成果

エネルギー変換システムにおける変換効率の向上と構造簡略化によるコスト低減・高信頼化のために、炭化 珪素（SiC）基セラミックスの、耐熱性材料の開発、苛酷環境特性や信頼性の向上、及び成形・接合・気密化 等の技術開発を行った。即ち、セラミックス複合材料プロセスの開発、ナノ・ミクロ構造とマクロ特性や耐環 境特性との相関の解明、環境影響損傷過程の理論的解析、機能附与の原理実証、各種評価技術の開発、実用機 器における材料システムとしての共存性の評価等である。炭化珪素繊維で強化された炭化珪素基複合材料

（SiC/SiC複合材料）を中心に、タングステン合金繊維により強化されたタングステン基複合材料（W/W複 合材料）、及びそれらの複合化要素部材の開発やこれらを用いるシステム要素の設計・製作・特性評価等を行 つた。開発した材料からモデル・システムを構成し、エネルギー変換機能と構造メンバーとしての力学特性な らびに耐久性能を実証し、高品位な基盤エネルギー・システムの見通しを得た。

\section{(1) $\mathrm{SiC} / \mathrm{SiC}$ 複合材料の開発研究}

各国の先進エネルギーシステムの概念設計において、 $\mathrm{SiC} / \mathrm{SiC}$ 複合材料の開発は、大型プロジェクトと研究 室レベルでの基礎研究に大別されるが、設計で想定されている材料特性には不十分な、又は欠落している要素 が多く、更には基本的な工学技術基盤の未整備等、本格的な使用検討を進めるには未成熟な状態であったので $\mathrm{SiC} / \mathrm{SiC}$ 複合材料開発の主たる課題を、基礎製造プロセス開発、特性評価ならびに複合機能構造化に設定し た。基礎製造プロセスの開発は、複合材料及びその構成要素の本質的な高性能化をはかり、新しい強化繊維の 開発、マトリックスの製造法や特性制御法の開発、繊維ーマトリックス界面制御の高度化、積層法、3方向強 化材料の製造法等の開発ならびに高度化を実施し、䋊維ーマトリックス界面の最適化を行った。特性評価は、 強度特性を中心とし、物理特性、化学特性の基礎的評価に加えて、原子レベルでのミクロ構造解析（特に繊維 ーマトリックス界面を対象とする）や、中性子照射効果及びその複合場の効果などエネルギー材料に特有の環 境因子に対する応答を研究した。材料の評価においては、複合材料の微視的レベルでの基礎特性やエネルギー システムにおける諸環境因子の効果に関する評価法を体系化し、標準化した。成形技術と接合技術の開発を進 め、応用を想定した部品を試作し、実物大の製造技術の実証にも成功した。

\section{（2） W/W複合材料の開発研究}

$\mathrm{W} / \mathrm{W}$ 複合材料は、 $1500^{\circ} \mathrm{C}$ 以上超高温での使用に耐え得ること、複合材料化により低温脆性を回避可能 なこと、熱伝導性に優れること、スパッ夕損耗性に優れること、及び、中性子照射環境で使用した場合の長期 的な誘導放射能レベルが極めて低いこと等、他の材料では代替できない魅力的な性能を有しながら、エネルギ ーシステムへの適用性は未知数であり、設計概念、要素技術共に既存技術の改善の範囲にあったので、本研究 で取り上げた。W/W複合材料開発においては、第一段階として複合材料設計概念の実証を行い、第二段階に おいて複合材料製造プロセスの検討および、プロセス実証試験を行った。特性評価としては、物理特性、化学 特性及び強度特性の基礎的特性の評価、原子レベルでのミク口構造解析、複合材料構成要素に対する中性子照 射効果及びその複合場の効果等、基礎的な検討での可能性を実証した。

主要な研究成果として超耐熱・耐環境性セラミックス複合材料プロセス技術（ナノ・インフィルトレーショ ン遷移共晶相〈NITE〉プロセス : 特許出願中) の開発に成功し、既存の工業材料では望めなかった高温強 度・耐酸化性・信頼性・気密性・接合性・コス卜効率等を極めて高い水準で満足するSiC基セラミックス複合 材料の製造を実証した。入口温度 $1700^{\circ} \mathrm{Cを}$ 超えるガスタービン実現の1ステップとなるもので、産業用エネル 
ギー機器や大型輸送機器、その他の熱利用機器への適用により、エネルギーの生産・変換・貯蔵・輸送・利用 に関わる効率や安全性の改善、環境負荷の低減が見込める。

4. 事後評価結果

4-1. 外部発表(論文、口頭発表等)、特許、研究を通じての新たな知見の取得等の研究成果の状況

- 論文発表（国内誌28件、国際誌194件）、招待、口頭講演（国内212件、国際236件）特許（国内14件、 海外9件）等、特許、数多くの論文を通じて主要な成果を発表しており、特に国際的発表が多いことは評価 される。

・ エネルギー効率を材料改善・改質によって向上させるという当初目標に対して、熱応力や、熱伝導性など の物性に優れた、超高温耐性のSiC／SiC複合材料を可能とし、材料開発、及び、その製造法の両面で、目 標以上の成果を達成している。

・特に、SiC繊維間の微細な空隙に高結晶性のSiCマトリックスを充填して、微細構造を制御し、液相焼結を 活用することにより高性能なセラミックス複合材料を製造するプロセスの開発に成功しており、アウトプ ットの複合材料が、従来の複合材料を、物性的にかなり上回るものであること、及びプロセスが比較的に 簡易であることなどから、実用への展開を大いに期待させるものである。

・従来、複合材料の基礎特性や工ネルギーシステム環境下での因子効果の評価は十分に確立されていなかつ たが、本研究で、評価法を開発すると共に体系化し、国際的に標準化したことは、複合材料研究開発の基 礎を固める上で、有効と認められる。

$4-2$. 得られた研究成果の科学技術への貢献

国際水準を抜く、特性の複合材料を得ることが出来た。国際的な連携のなかで、ブレークスルーとも評すべ き成果を挙げており、科学的にも、又応用的に見ても国際レベルの研究として貢献度が高い。特に、液相焼結 を利用したプロセスの、ナノレベルの制御法は、複合材料開発におけるナノテクノロジーの展開に、かなりの インパクトを与えるものと思われる。実用を想定した、部品レベルの強度実験により、応用評価にも、ある程 度成功しており、実際に、各方面から、引き合いを受けるなど実用への展望も期待させる。又、材料基礎特性 などの評価法を体系的に標準化して、今後の、複合材料研究開発の基盤整備に貢献した。

$4-3$. その他の特記事項

特になし

$\leq<$ 環境低負荷トップ

This page updated on September 12, 2003

Copyright(C)2003 Japan Science and Technology_Corporation 